Dr ALEKSANDAR ŽIVOTIĆ, vanredni profesor

Filozofski fakultet, Univerzitet u Beogradu

Beograd, Republika Srbija

UDK 327.5(497.1:47)"1948/1953"

aleksandar.zivotic@f.bg.ac.rs

94(497.1)"1948/1953"

originalan naučni rad / original scientific paper

primljeno / received: 20.6.2021.

prihvaćeno / accepted: 24. 11. 2021.

https://doi.org/10.29362/ist20veka.2022.1.ziv.107-128

\title{
STRAH ILI REALNOST? MOGUĆNOST SOVJETSKE VOJNE INTERVENCIJE U JUGOSLAVIJI 1948-1953.
}

APSTRAKT: U radu se na osnovu dostupnih objavljenih i neobjavljenih arhivskih izvora prevashodno sovjetskog i jugoslovenskog porekla, kao i relevantne istoriografske $i$ memoarske literature analizira pitanje postojanja sovjetskih namera za vojnu intervenciju u Jugoslaviji u vreme sukoba između nje i zemalja Informbiroa. Predstavljene su ekonomske i demografske okolnosti koje su uticale na kreiranje sovjetskog pristupa razvoju sopstvenih $i$,,satelitskih" vojnih snaga. Posebno su razmatrane promena geopolitičkog položaja Jugoslavije usled sukoba $s$ ranijim saveznicima $i$ vojnog $i$ političkog približavanja zapadnom svetu, kao $i$ zapadna percepcija jugoslovenske vojne ugroženosti $i$ sposobnosti jugoslovenskih oružanih snaga da se odupru eventualnoj sovjetskoj agresiji.

KLJUČNE REČI: Jugoslavija, Sovjetski Savez, Velika Britanija, Sjedinjene Američke Države, Informbiro, vojna intervencija

Jugoslovensko-sovjetski sukob čija je vidljiva faza započela u leto 1948, osim političkih, ekonomskih, ideoloških i društvenih dimenzija, imao je izraženu i vojnu stranu. Sveopšta konfrontacija koja je od sredine 1949. počela da dobija obrise sveobuhvatnog sukoba, nametnula je i pitanje moguće sovjetske vojne intervencije u Jugoslaviji koja bi za cilj imala smenu državnog i partijskog rukovodstva i njegovu zamenu prosovjetskim režimom koji bi potom povratio Jugoslaviju u sovjetsko okrilje. Na jugoslovenskoj strani se strahovalo da bi na Jugoslaviju, kao zemlju koja se našla u sukobu s dojučerašnjim saveznicima, mogao biti izvršen vojni napad jer zapadni svet s kojim je socijalistička Jugoslavija bila u permanentnom sukobu od maja 1945, ne bi intervenisao u jugoslovensku korist. Strah jugoslovenskog političkog i vojnog vođstva od mogućeg vojnog napada s istoka brzo se preneo na stranice dnevne štampe i propagandnih brošura, a potom je korišćen u psihološke i propagandne svrhe kao sredstvo masovne unutrašnje mobilizacije i jačanja unutrašnjeg jedinstva u cilju očuvanja poretka u zemlji. To je koincidiralo s nizom mera koje su od stanov- 
ništva zahtevale izuzetna odricanja u uslovima izraženog niskog životnog standarda, svakovrsne represije i osećaja spoljnopolitičke izolovanosti. Zato ćemo nastojati da na osnovu raspoloživih izvora, pre svega sovjetskog porekla, odgovorimo na pitanje koliko je jugoslovenski strah od sovjetske vojne intervencije bio realan $\mathrm{i}$ da li se za široko rasprostranjenu i često nenaučno eksploatisanu tezu o sovjetskim vojnim pripremama protiv Jugoslavije mogu naći uporišta u poznatim i dostupnim istorijskim izvorima. Odnosno, neće biti reči o jugoslovenskim strahovima, sumnjama i strepnjama, vojnim i odbrambenim pripremama koje je preduzimalo jugoslovensko državno i vojno vođstvo, kao i procenama mogućih sovjetskih vojnih i političkih poteza, već ćemo nastojati da što je moguće vernije predstavimo stvarne vojne namere, kao i vojne i političke pozicije Sovjetskog Saveza i njegovih saveznika u jugoslovenskom okruženju. ${ }^{1}$

Strah od moguće sovjetske vojne intervencije uz jačanje vojnih efektiva sovjetskih saveznika - jugoslovenskih suseda u cilju snaženja pritisaka na Jugoslaviju i njeno državno, partijsko i vojno vođstvo koji je jugoslovenskoj javnosti prikazivan kao stvaran i ostvarljiv, u domaću istoriografiju ušao je u trenucima kad se tema jugoslovensko-sovjetskog sukoba nametala kao naučna istoriografska tema. Nedostupnost najvažnijih dokumentarnih izvora, kako s jugoslovenske, tako i sa sovjetske strane, činila je da se takva tvrdnja preuzeta sa stranica ondašnje štampe gotovo mehanički preuzima i potom inkorporira $\mathrm{u}$ istoriografske radove ${ }^{2}$ ili da se od strane učesnika i neposrednih svedoka zbivanja prihvata kao realna. ${ }^{3}$ Kasnije, s protokom vremena i temeljnijim istraživanjima dokumentarnih izvora koji su postepeno postajali dostupniji, pojavila se i sumnja u izvornu zasnovanost takvih shvatanja. Iako su na bazi novijih istraživanja pomenute postavke uglavnom odbačene, i danas se često u delu istoriografije nameću kao relevantne. ${ }^{4}$

\footnotetext{
${ }^{1} \mathrm{O}$ prirodi sukoba između Jugoslavije i zemalja Informbiroa opširnije: Milovan Đilas, Vlast i pobuna (Beograd: Književne novine, 1990); Milovan Đilas, Razgovori sa Staljinom (Beograd: Književne novine, 1991); Čedomir Štrbac, Svedočanstva o 1948 (Beograd: Zavod za udžbenike i nastavna sredstva, 1989); Vladimir Dedijer, Izgubljena bitka Josifa Visarionoviča Staljina (Sarajevo: Svjetlost, 1968); Бранко Петрановић, Југославија на размеђу 1945-1950 (Подгорица: ЦАНУ, 1998); Бранко Петрановић, Велика шизма. Четрдесетосма (Подгорица: ЦИД, 1999); Анатолий С. Аникеев, Как Тито от Сталина ушел: Югославия, СССР и США и началъны период холодной войны 1945-1957 (Москва: ИнСлав РАН, 2002); Артем А. Улунян, СССР, страны народной демократии и революиионное движение в Греции 1944-1950 (Москва: ИВИ АН СССР, 1988); Артем А. Улунян, Балканы. Горячий мир холодной войни 1945-1960 (Москва: ИВИ РАН, 2001); J. Vykoukal, В. Litera, М. Tejchman, Východ, vznik, vývoj a pozpad sovětskeho bloku 1944-1989 (Praha: Libri, 2000); Юрий Гиренко, Сталин-Tито (Москва: ИПЛ, 1991); Милан Терзић, Михајло Басара и Дмитар Тасић, Југословенска (народна) армија и Информбиро. Зборник докумената (Београд: Службени гласник, 2015); Леонид Я. Гибианский, „К истории советско-югославского конфликта 1948-1953: Секретная советскоюгославо-болгарская встреча в Москве 10. февраля 1948. года“, I, Славяноведение, бр. 3, (1991), 12-23; II, Славяноведение, бр. 4, (1991), 4-36; III, Славяноведение, бр. 1, (1992), 42 56; IV, Славяноведение, бр. 3, (1992), 35-51.

2 Vladimir Dedijer, Novi prilozi za biografiju Josipa Broza Tita III (Zagreb: Mladost, 1984), 427-446.

${ }^{3}$ Gojko Berić, Zbogom XX. stoljeće. Sjećanja Ive Vejvode (Zagreb: Profil, 2013), 119-125.

${ }^{4}$ Миле Бјелајац, Дипломатија и војска. Србија и Југославија 1901-1999 (Београд: Одбрана, 2010), 227-230.
} 
Da bismo odgovorili na pitanje vezano za istoriografsku zasnovanost pomenutih tvrdnji moramo se prevashodno osvrnuti na izvore na kojima se one temelje. Karel Kaplan, visoki funkcioner Komunističke partije Čehoslovačke i istoričar, izneo je u svojim sećanjima svedočenje čehoslovačkog ministra odbrane Alekseja Čepičke da je Josif Visarionovič Staljin tokom januara 1951. najavio početak obračuna sa kapitalističkim zemljama. ${ }^{5}$ Takođe, slične izjave je davao sovjetski maršal Konstantin Rokosovski u razgovorima sa čelnicima italijanske komunističke partije. ${ }^{6}$ Proslavljeni sovjetski maršal Georgij Žukov je, prema neproverenim i nedovoljno pouzdanim tvrđenjima generala Pavla Jakšića, o tome pričao u razgovorima sa predstavnicima Jugoslovenske narodne armije prilikom svoje posete Jugoslaviji 1957. Navodno, tom prilikom je maršal Žukov svojim jugoslovenskim sagovornicima govorio o postojanju planova za izvođenje desanta na važnije jugoslovenske gradove i „dopuštao mogućnost“ da je važnu ulogu u odvraćanju od napada odigralo i predviđanje široko rasprostranjenog gerilskog otpora sovjetskim trupama, odnosno kombinovanih akcija transformisane i decentralizovane operativne armije udružene s teritorijalnim gerilskim odredima na ispresecanim frontovima. ${ }^{7}$

O pretpostavljenom mestu i ulozi Jugoslavije u sklopu mogućeg opšteg rata između SSSR-a i njegovih saveznika s jedne i zapadnih zemalja s druge strane najrečitije govori izjava mađarskog generala Bele Kiraljija koji je nakon Mađarske revolucije 1956. izbegao na Zapad. General Kiralji u svom svedočenju pisanom više od dve decenije posle opisanih događaja ističe da su u Mađarskoj u januaru 1951. održane velike štabne ratne igre tokom kojih je uvežbavana mogućnost dejstvovanja mađarske armije protiv jugoslovenskih vojnih snaga, a da su vojne pripreme za napad na Jugoslaviju započele još tokom 1949. kada je izvršena radikalna reorganizacija mađarskih oružanih snaga. Istovremeno, na rukovodeća mesta ostalih armija sovjetskih saveznika postavljani su, prema njemu, sovjetski generali ili generali u čiju odanost SSSR-u sovjetsko rukovodstvo nije sumnjalo. ${ }^{8}$ U Mađarskoj je posle imenovanja Mihalja Farkaša za ministra odbrane za njegovog zamenika postavljen Šandor Nogradi, ${ }^{9}$ koji je u Mađarsku došao zajedno sa Crvenom armijom 1944. U Poljskoj je ministar odbrane postao proslavljeni sovjetski maršal Konstantin Rokosovski koji je

\footnotetext{
5 Марк Крамер, „Советско-югославский конфликт, советская военная политика о попытки Сталина вернуть себе контроль над Югославией: переоценка“, у: История сталинизма: Итоги проблемы изучения, уредник Елена Кандрашина (Москва: РОССПЭН, 2011), 256-274.

${ }^{6}$ Darko Bekić, Jugoslavija u Hladnom ratu. Odnosi s velikim silama 1949-1955 (Zagreb: Globus, 1988), 237-239.

${ }^{7}$ Pavle Jakšić, Nad uspomenama II (Beograd: Rad, 1990), 53.

${ }^{8}$ Bela K. Kiraly, "The Aborted Soviet Military Plans Against Tito's Yugoslavia”, in: At the Brink of War and Peace. The Tito - Stalin Split in a Historic Perspective, editor Wayne Vucinich (New York: East European Monographs 1982), 273-278.

9 Tokom Drugog svetskog rata Šandor Nogradi je bio urednik mađarskog radija „Košut“ u Sovjetskom Savezu i komandant mađarskog dela partizanske škole u Kijevu. Od oktobra 1944. komandovao je mađarskim partizanskim odredom u sastavu Drugog ukrajinskog fronta Crvene armije na čijem čelu se vratio u Mađarsku, gde je do postavljenja na mesto pomoćnika ministra odbrane obavljao niz partijskih dužnosti.
} 
inače bio poljskog etničkog porekla, dok je u Bugarskoj na mesto načelnika Generalštaba postavljen Asen Grekov ${ }^{10}$ za koga se čak tvrdilo da je sovjetski general. U Čehoslovačkoj je na mesto ministra odbrane postavljen dotadašnji ministar pravde Aleksej Čepička, čovek bogate partijske prošlosti. ${ }^{11}$ Po generalu Kiraljiju, mađarskoj strani nije bio dostavljen potpun ratni plan. Samo je sugerisano da će u akciji protiv Jugoslavije učestvovati i rumunske, bugarske, albanske i sovjetske trupe, kao i manji kontingenti poljske i čehoslovačke armije. Prema njegovoj izjavi, glavnina mađarske vojske bi, u sadejstvu sa jednom rumunskom armijom, činila udarni ešelon koji je imao zadatak da zauzme prostor između Tise i Dunava i formira mostobran na uzvišenjima Fruške gore. Sovjetske trupe bi u tom slučaju zauzele Beograd. Drugi deo mađarskih snaga bi izvršio napad u pravcu Ljubljane, prethodno forsiravši Dravu. I rumunske snage bi nastupale na dva pravca: manjim delovima na prostoru Banata i većim, iz pravca Vlaške, u sadejstvu sa bugarskim snagama ka dolini Velike Morave. Ostatak bugarskih snaga dejstvovao bi na više pravaca ka Skoplju kako bi presekao jugoslovenske snage na dva dela. Drugi udarni ešelon predstavljale bi snažne sovjetske motorizovane i oklopno-mehanizovane divizije koje bi imale zadatak da razbiju jugoslovenske snage na više manjih izolovanih grupacija. ${ }^{12}$

Kao što se iz navedenog može videti, radi se o izjavama i sećanjima pojedinih učesnika i svedoka zbivanja koji nisu bili u mogućnosti da se nedvosmisleno uvere u stvarne namere sovjetskog političkog i vojnog rukovodstva prema Jugoslaviji. Na drugoj strani, i sam Josip Broz Tito je svedočio u svom dnevniku ne navodeći izvor informacija da je jugoslovenska strana krajem 1950. raspolagala sasvim pouzdanim podacima da su Sovjeti preko svojih satelita pripremali napad na Jugoslaviju tokom prve polovine 1951. Po njemu, sovjetski plan je podrazumevao napad na Jugoslaviju kroz nekoliko faza. U prvoj fazi bi navodno bila izazvana pobuna $\mathrm{u}$ jednom od delova Jugoslavije, a potom bi od strane Sovjeta i uz pomoć njihovih saveznika u zemlju bile ubačene ,jugoslovenske oslobodilačke brigade" koje bi imale zadatak da dejstvuju protiv jugoslovenskih oružanih snaga ,pod firmom borbe jugoslovenskih naroda“. Bio je uveren da će opisani koraci biti preduzeti sa sovjetske strane kako bi bila stvo-

\footnotetext{
${ }^{10}$ Oktobra 1949. vođstvo Bugarske komunističke partije zahtevalo je od sovjetskih vlasti da se u Bugarsku uputi sovjetski oficir koji bi preuzeo dužnost načelnika generalštaba pošto su se bugarske oružane snage nalazile u procesu reorganizacije i udaljavanja s najviših pozicija nekadašnjih generala iz perioda bugarske monarhije. Stoga se, u uslovima ubrzanog jačanja i modernizacije, osećao nedostatak sposobnih oficira za obavljanje najviših dužnosti u vojsci. Sa sovjetske strane je stigao negativan odgovor, uz objašnjenje da se na čelu bugarske vojske mora nalaziti bugarski oficir. Zato je 9. novembra 1949. na mesto načelnika generalštaba postavljen general Asen Grekov koji je u jesen 1944. stupio u bugarske oružane snage kao pukovnik Crvene armije. Grekov, koji je aktivno učestvovao u Septembarskom ustanku 1923, od 1926. živeo je u SSSR-u kao politički emigrant. Kao nekadašnji bugarski rezervni oficir sa zavidnim ratnim iskustvom iz Prvog svetskog rata, do 1944. gradio je vojnu karijeru u redovima Crvene armije gde je završio najviše vojne škole i obavljao niz komandnih, štabnih i nastavnih dužnosti. Любомир Огнянов, Политическата система в България 1949-1956 (София: Стандарт, 2008), 143.

${ }^{11}$ D. Bekić, n. d., 237-239.

${ }^{12}$ B. K. Kiraly, op. cit., 273-288.
} 
rena pogodna osnova za njihovo direktno mešanje zajedno sa svojim satelitima. Takve informacije su presudno uticale na preduzimanje adekvatnih vojnih $\mathrm{i}$ odbrambenih priprema od strane jugoslovenskih državnih i vojnih vlasti. ${ }^{13}$ Iako nije moguće sa sigurnošću utvrditi poreklo informacija kojima je Josip Broz raspolagao, poznato je da je lider mađarskih komunista Maćaš Rakoši u razgovorima sa sovjetskim predstavnicima iznosio svoj stav da je u Jugoslaviji ,neophodna oružana borba“ uz organizovanje partizanskih odreda jer se „Titova klika ne može ukloniti propagandom“. ${ }^{14}$ Očigledno se, makar u vodećim krugovima komunističkih partija jugoslovenskih suseda, razmatrala mogućnost otpočinjanja vojnih dejstava u Jugoslaviji na nivou organizovanja gerilskih grupa.

Da bi se preciznije odgovorilo na pitanje postavljeno na početku rada, moramo se osloniti na dostupne izvore sovjetskog porekla. Šta je podsticalo sovjetska razmišljanja o mogućoj vojnoj intervenciji, a šta ih je u tim razmišljanjima navodilo na sumnje da bi takav korak mogao izazvati šire posledice koje bi u osnovi kompromitovale kako sovjetsku poziciju u istočnom delu Evrope, tako i u odnosu na zapadni svet? Već sredinom 1949. na sovjetskoj strani se formiralo uverenje da politički i ekonomski pritisak na Jugoslaviju ne daje očekivane rezultate i da, uprkos teškom stanju u zemlji, jugoslovensko partijsko vođstvo uspeva da održava svoj politički monopol i da se efikasno suprotstavlja svojim dojučerašnjim saveznicima. Zato se unutar najviših sovjetskih vojnih i državnih struktura počelo razmišljati o mogućnosti masovne primene vojne sile u cilju smenjivanja jugoslovenskog partijskog vođstva i povratka političke i vojne kontrole nad Jugoslavijom. Ipak, donosiocima najvažnijih odluka u Kremlju se takva mogućnost rešenja konflikta činila sasvim neprivlačnom i nepopularnom. Sovjete su mnoge okolnosti navodile na zaključak da se ipak treba uzdržati od primene vojne sile. Najvažnije od njih bile su: mogućnost susreta sa upornom odbranom na jugoslovenskoj strani, potreba za angažovanjem masovnih vojnih snaga u trenucima kad je sovjetska armija nakon prelaska na mirnodopski način funkcionisanja bila drastično umanjena i rasuta na velikom prostoru van sovjetskih granica i u uslovima kad je sovjetska privreda išla putem prelaska s ratnog na mirnodopski kolosek koji je imao za cilj podizanje ličnog standarda stanovništva uz eliminaciju nasleđa ratne ekonomije. Takođe, neizvestan i otežan način snabdevanja trupa koje bi učestvovale u intervenciji, a koje je trebalo snabdevati koristeći se nepovoljnom i nerazvijenom saobraćajnom infrastrukturom istočnoevropskih zemalja i same Jugoslavije, mogućnost provociranja reakcije Zapada što je postalo još izvesnije nakon prvih jugoslovenskih vojnih aranžmana sa Zapadom sredinom 1951. Sve te okolnosti dovodile su realizaciju takve zamisli pod znak pitanja. Nikita Hruščov je u svojim kasnijim sećanjima iznosio uverenje da bi se Staljin svakako odlučio na takav korak da je Jugoslavija imala zajedničku granicu sa

\footnotetext{
${ }^{13}$ Перо Симић, Титов дневник (Београд: Вечерње новости, 2009), 66-67, 81-82, 85-89.

${ }^{14}$ Российский государственный архив социально-политической истории (РГАСПИ), ф. 575, о. 1, д. 94, л. 149-150, Докладная записка С. Г. Заволожщского Л. С. Баранову о беседе с М. Ракоши, 11 июля 1949.
} 
Sovjetski Savezom. ${ }^{15}$ Smeo, ali za sada neproverljiv Hruščovljev zaključak svakako nije moguće potvrditi, ali on sam po sebi nameće i otvara pitanje uloge geografskog položaja Jugoslavije u sovjetskim vojnim projekcijama kao dominantno brdsko-planinske zemlje udaljene od sovjetskih granica i široko otvorene ka Mediteranu i srednjoj Evropi kao jednog od odlučujućih geostrategijskih faktora koji su uticali na sovjetsku stranu da ne preduzme vojne akcije na Balkanu.

Ipak, mnoga svedočenja govore o tome da je sam Staljin imao ozbiljne rezerve prema svakoj ideji koja bi podrazumevala odlučujuću vojnu akciju bilo gde na evropskom tlu. U prilog takve teze, pored njegovog dobro poznatog odnosa prema međunarodno preuzetim obavezama tokom i na kraju Drugog svetskog rata, govore i ekonomske i demografske okolnosti u kojima se našao Sovjetski Savez na kraju Drugog svetskog rata i nekoliko godina po njegovom okončanju. ${ }^{16}$ Naličje sovjetske pobede u ratu je predstavljalo kolorit posledica ratnih razaranja, ekonomskog pustošenja i demografske katastrofe. Tokom ratnih godina zemlja je izgubila tri četvrtine svog ukupnog predratnog nacionalnog bogatstva. Na okupiranim teritorijama industrija je bila gotovo uništena, a na ostatku teritorije u potpunosti stavljena u funkciju ratne proizvodnje. Ukupan broj stanovnika iz $1940-$ 196 miliona ljudi smanjio se za 26 miliona i godine 1946. iznosio je 170 miliona. ${ }^{17}$ Sovjetsko rukovodstvo je jednim od svojih glavnih zadataka na kraju rata smatralo smanjenje ukupnih vojnih efektiva, izgradnju moderne oružane sile opremljene novim modelima naoružanja i vojne opreme i povratak industrije s ratnog na mirnodopski kolosek, odnosno proizvodnju za civilne potrebe, posebno robe široke potrošnje kako bi se tokom prve posleratne decenije dostigao nivo životnog standarda $\mathrm{i}$ industrijske proizvodnje iz poslednje mirnodopske godine. Proizvodnja konvencionalnih sredstava naoružanja i vojne opreme iz godina rata je drastično umanjena. Postojeći viškovi su rapidno uklanjani iz arsenala Crvene armije i u značajnoj meri ustupani armijama istočnoevropskih saveznika u vidu direktne pomoći ili putem povoljnih kreditnih aranžmana. ${ }^{18}$

Takođe, kolosalni ratni napori, ekonomska razaranja, kao i glad tokom 1946. i 1947. neizostavno su usmeravali državnu vlast ka rešavanju najvažnijih privrednih problema. U takvim okolnostima kao sasvim prirodno rešenje nametala se politika smanjenja vojne proizvodnje i sveopšte rekonverzije postojećih industrijskih kapaciteta s ratne na mirnodopsku proizvodnju. Sam započeti proces je u stvarnosti imao ograničen karakter. Već tokom 1946, a posebno 1947, odnos između vojne i civilne proizvodnje se stabilizovao, dok je u toku 1948. vojna proizvodnja ponovo počela da raste. Ukupni vojni rashodi su se stabilizovali 1947. na nivou od 67 milijardi rubalja što je bilo znatno više od predratnog nivoa iz 1940, koji je iznosio 56,7 milijardi rubalja. Proces sveukupnog smanje-

\footnotetext{
${ }^{15}$ Никита С. Хрущев, Время, люди, власть, кн. 3 (Москва: Московские новости, 1994), 118.

${ }^{16}$ Ирина Быстрова, Советский военно-промышленный комплекс: проблемы становления и развития 1930-1980-е годы (Москва: ИВИ РАН, 2006), 233.

${ }^{17}$ Исто.

18 Исто, 236-238; Александар Животић, Југословенско-совјетске војне супротности (1947-1957). Искушења савезништва (Београд: Архипелаг, 2015), 102-103.
} 
nja vojne proizvodnje se direktno ticao starijih tipova naoružanja i vojne opreme koji više nisu bili potrebni u većim količinama. Stoga je tokom prve posleratne ,petoletke“ akcenat bio na razvoju novih sistema naoružanja i vojne opreme, što je tek početkom 50-ih godina stvorilo pogodnu osnovu za preoružanje celokupnih sovjetskih oružanih snaga. ${ }^{19}$

Nasuprot tome, pomenuti general Bela Kiralji koji se u tom periodu nalazio na jednoj od najznačajnijih pozicija u mađarskoj armiji tvrdi da je isključivo žestoka američka reakcija na napad Severne na Južnu Koreju u junu 1950. naterala Staljina da zaustavi pripreme za napad na Jugoslaviju. ${ }^{20}$ Ipak, ovo tvrđenje moramo uzeti s rezervom, posebno ako se ima $u$ vidu da se sovjetsko vođstvo nakon toga ohrabrilo usled kineskog ulaska $u$ rat. Na taj način je zaustavljeno američko napredovanje tako da je pomenuti Staljinov strah mogao imati isključivo kratkoročno dejstvo u smislu privremenog odustajanja od nameravane vojne intervencije ukoliko je uopšte takve namere i razmišljanja bilo. Naime, tokom tajnog savetovanja u Moskvi januara 1951, Staljin je izjavio da su SAD pokazale da nisu bile u stanju da vojno slome NR Kinu i Severnu Koreju i da kao takve nisu u mogućnosti da započnu treći svetski rat jer su pokazale da su nesposobne da vode čak i mali rat. Na drugoj strani, do početka rasplamsavanja sukoba na Korejskom poluostrvu sovjetske vojne pripreme za intervenciju u Jugoslaviji nisu odmakle dalje od maglovite ideje, a jačanje vojnih snaga sovjetskih saveznika u jugoslovenskom okruženju usledilo je tek nakon prelaska sukoba u Koreji u odlučujuću fazu. Kiraljijeve teze su na bazi mađarskih dokumentarnih izvora osporene od strane istoričara Lasla Ritera koji je utvrdio da su na mađarskoj strani postojali ratni planovi isključivo defanzivnog karaktera namenjeni za slučaj ugrožavanja Mađarske s jugoslovenske teritorije, kako od strane jugoslovenskih snaga, tako i vojnih snaga NATO nakon 1951, ${ }^{21}$ dok Mark Kramer iznosi tezu da su se dati planovi mogli lako prilagoditi situaciji i uspešno pretvoriti iz defanzivnih u ofanzivne te da iz tog razloga nisu imali isključivo odbrambeni karakter.

Ipak, i sam Kramer prenebregava okolnost da je za ofanzivno vođenje operacija potrebno sasvim drugačije grupisanje, ešeloniranje, pa i angažovanje raspoloživih snaga. ${ }^{22}$ Svakako, posle zaključenja sporazuma o vojnoj pomoći između Jugoslavije i SAD 14. novembra 1951. i obimnog prijema zapadne vojne i ekonomske pomoći, Jugoslavija je od strane Sovjetskog Saveza i njegovih satelita smatrana pridruženim delom zapadne vojne koalicije, a njena teritorija potencijalnim prostorom s koga bi moglo doći do vojnog ugrožavanja.

19 Ирина Быстрова, „Военная политика сталинского руководства: основные вехи и механизмы осуществления“, у: Сталин и холодная война, редактор А. О. Чубарьян (Москва: ИВИ РАН, 1998), 232.

${ }^{20}$ B. K. Kiraly, op. cit., 286-287.

${ }^{21}$ Laszlo Ritter, "War in Tito's Yugoslavia? The Hungarian Army in early Cold War Soviet strategies", u: Balkanski pakt 1953-1954. Zbornik radova, urednik Milan Terzić (Beograd: Vojnoistorijski institut, 2008), 251-281. Riterove teze prihvata i Dmitar Tasić u svom radu „Неостварена претња (могућност совјетско-сателитске агресије на ФНРЈ 1948-1953)“, Војноисторијски гласник, бр. 1, (2009), 81-98.

${ }^{22}$ М. Крамер, „Советско-югославский конфликт...“, 264-267. 
Često se kao dokaz agresivnih vojnih namera prema Jugoslaviji uzimaju i mere koje je Sovjetski Savez preduzeo na planu jačanja vojnih efektiva svojih istočnoevropskih saveznika. Sovjetski saveznici u jugoslovenskom okruženju su u momentu izbijanja jugoslovensko-sovjetskog sukoba raspolagali ograničenim vojnim potencijalima. Bugarska, Rumunija i Mađarska su bile zemlje koje su u Drugom svetskom ratu učestvovale na strani Osovine i slovom mirovnih ugovora njihovi vojni kapaciteti su bili ograničeni isključivo na nivou koji je omogućavao prostu zaštitu državnih granica i očuvanje stabilnog poretka u zemlji. Albanija, kao zemlja koja se do leta 1948. nalazila pod svojevrsnim jugoslovenskim političkim starateljstvom, raspolagala je slabim vojnim snagama koje su se do početka sukoba s Jugoslavijom u operativnom i logističkom smislu nalazile u punoj zavisnosti od Jugoslavije. ${ }^{23}$ Vojna situacija tih zemalja se nije izmenila samo kao posledica sukoba s Jugoslavijom, već prvenstveno usled dešavanja globalnog karaktera. Naime, osnivanje Severnoatlantskog vojnog saveza čiji je jedan od osnivača bila i Italija koja je takođe pripadala krugu poraženih zemalja izazvalo je hitnu sovjetsku diplomatsku reakciju. Pošto sovjetski diplomatski pritisak na SAD, Veliku Britaniju i Francusku nije dao rezultat, na sovjetskoj strani je doneta odluka da se pristupi preduzimanju recipročnih mera, odnosno da se sa sovjetskih saveznika koji su u prethodnom ratu učestvovali na poraženoj strani skine teret vojnih ograničenja i pristupi izgradnji savremenih vojnih snaga kompatibilnih sovjetskim, opremljenim i naoružanim po sovjetskim normama i principima, kako bi u dogledno vreme bili stvoreni uslovi za stvaranje jedinstvenog vojnopolitičkog saveza pod sovjetskim vođstvom. ${ }^{24}$

U samoj stvarnosti taj proces nije mogao biti momentalan i podrazumevao je duži usmeren napor sovjetske strane na materijalnom, kadrovskom i savetodavnom planu. U trenutku kad se pristupilo jačanju vojnih snaga sovjetskih saveznika, ni političke prilike u tim zemljama nisu išle na ruku sovjetskim stremljenjima. Iako na vlasti, tamošnje komunističke partije još uvek nisu konsolidovale svoj politički uticaj i uspostavile apsolutnu društvenu dominaciju. I dalje su, iako su držale ključne poluge vlasti, bile u širokim koalicijama sa socijalističkim, socijaldemokratskim i zemljoradničkim partijama. Politički monopol komunista u tim zemljama još uvek nije bio u potpunosti definisan što se u znatnoj meri odražavalo na stanje i u njihovim oružanim snagama u kojima su važne položaje još uvek držali oficiri školovani i stručno formirani u starom sistemu, sasvim suprotnom po svom duhu sovjetskom koji se ubrzano nametao. ${ }^{25}$ Sovjetski vojni savet-

${ }^{23}$ O jugoslovenskom vojnom angažmanu u Albaniji do 1948. opširnije: Bojan Dimitrijević, JNA od Staljina do NATO pakta (Beograd: Službeni list SCG, 2006); Александар Животић, Jугославија, Албанија и велике силе, 1945-1961 (Београд: Архипелаг, 2011); Александар Животић, Југословенско-совјетске војне супротности (1947-1957). Искушења савезништва (Београд: Архипелаг, 2015).

24 Архив внешней политики Российской федерации (АВПРФ), фонд 123 - Референтура САД (ф. 123), опис 34 (о. 34), дело 1 (д. 1), папка 225 (п. 225), лист 104 -112 (л), Нота МИД СССР от 20 апрелья 1950.

${ }^{25}$ АВПРФ, ф. 123, о. 33, д. 20, п. 218, л. 24, Оценка МИД СССР 19 июлья 1949; Татьяна Волокитина, Галина Мурашко, Альбина Носкова, Татьяна Покивайлова, Москва и Во- 
nici u njihovim oružanim snagama još uvek nisu bili brojni i samim tim nisu bili u stanju da ubrzano utiču na preobražaj armija svojih domaćina. ${ }^{26} \mathrm{U}$ momentima kad je započeo proces preoblikovanja savezničkih vojnih snaga, njihova ukupna jačina u jugoslovenskom okruženju je iznosila 28 divizija sa oko 350.000 ljudi dok je samo jugoslovenska armija u to vreme imala oko 400.000 ljudi pod oružjem. Konkretno, u pogledu Bugarske i njenih oružanih snaga glavni sovjetski vojni savetnik u toj zemlji general Petruševski smatrao je početkom 1949. da bugarska armija napreduje u kadrovskom, materijalnom i organizacionom smislu, ali da se u njoj mora još mnogo raditi jer se ona ,ubraja u armije koje nisu u stanju da vode savremeni boj i savremene operacije“, da je u ranijem periodu njena borbena moć precenjivana, kao i da joj nedostaju sposobni kadrovi koji bi bili u stanju da planiraju, organizuju i izvode krupne savremene operacije. Konstatovao je i da joj nedostaju savremeno naoružanje, kao i savremena organizacija i obuka. Sem toga, sa sovjetske strane se smatralo da je nesposobnost bugarske armije za izvođenje savremenih operacija dobrim delom podstaknuta i delovanjem projugoslovenskih kadrova što je doživljavano kao posledica ranije bliskosti. ${ }^{27}$ Slično je bilo u mađarskoj vojsci gde su sa sovjetske strane kao glavni oponenti ubrzanoj sovjetizaciji mađarskih oružanih snaga označeni stari oficirski kadrovi koji su se, prema njihovoj oceni, protivili ubrzanoj promociji novih oficira koji su dolazili iz seoskih i radničkih krugova pri čemu su po vojno-stručnoj liniji nailazili često na podršku sovjetskih vojnih savetnika. ${ }^{28}$ Radi podizanja opšteg nivoa operativnih sposobnosti mađarske vojske bilo je potrebno ubrzati sovjetske isporuke naoružanja i vojne opreme kako bi se došlo do unifikacije dve armije. Uz to, imperativno se insistiralo na „čišćenju“ armije od „starih oficirskih kadrova“ kako bi ona ubrzano postala ,proleterska“" ${ }^{29}$

сточная Европа. Становление политических режимов советского типа (1948-1953): Очерки истории (Москва: РОССПЭН, 2008), 596-616.

${ }^{26} \mathrm{O}$ radu sovjetskih vojnih savetnika u oružanim snagama istočnoevropskih zemalja opširnije: $\mathrm{T}$. Волокитина, Г. Мурашко, А. Носкова, Т. Покивайлова, Москва и Восточная Европа..., 617-659. Početkom 1950. u Albaniji je bilo 17, Bugarskoj 20, Rumuniji 25 i Čehoslovačkoj 4 vojna savetnika, ukupno 66 sovjetskih vojnih savetnika u zemljama Istočne Evrope (РГАСПИ, ф. 17, о. 116, д. 487, л. 36-43, Решение Секретариата ЦК ВКП(б) о включении в номенклатуру должностей ЦК ВКП (б) военных советников в армиях союзных стран, 3 февраля 1950). To je višestruko manje od broja sovjetskih vojnih savetnika koji su se nalazili u Jugoslaviji pre otpočinjanja sukoba između nje i zemalja Informbiroa. Tadašnji broj od 90 sovjetskih vojnih savetnika u Jugoslaviji je odgovarao broju angažovanih sovjetskih vojnih stručnjaka u armijama ratnih saveznika - Poljskoj gde ih je bilo 90 i Čehoslovačkoj gde je bilo 86 sovjetskih vojnih stručnjaka. Александар Животић, Југословенско-совјетске војне супротности 1947-1957 (Београд: Архипелаг, 2015), 43-45.

27 Архив Президента Российской Федерации (АПРФ), ф. 3, о. 64, д. 279, л. 54-72, Сопроводительно письмо министра вооруженных сил СССР Н. А. Булганина И. В. Сталину с приложением доклада главного военного советника в Болгарии генерал-лейтенанта А. В. Петрушевского о положении в стране, 7 января 1949.

28 АВПРФ, ф. 77, о. 29, п. 132, д. 8, л. 54-63, Из дневника временного поверенного в делах СССР в Венгрии М. В. Смирнова, 11 ноября 1949.

29 АВПРФ, ф. 7, о. 22, п. 24, д. 4, л. 44-45, Запись беседы заместителя иностранных дел СССР А. Вишинского с послом Венгрии 3. Мольнаром, 12 марта 1949. 
Slično stanje je vladalo u redovima rumunskih vojnih snaga gde se ubrzano insistiralo na udaljavanju iz aktivne službe starih kadrova i njihovoj zameni mlađim oficirima tek izašlim iz vojnih akademija uz školovanje u sovjetskim vojnim školama i akademijama i prisustvo sovjetskih vojnih savetnika koji bi pomagali u reorganizaciji vojske, njenom usklađivanju sa sovjetskom vojnom praksom i ovladavanjem naoružanjem i vojnom opremom koja je dostavljana iz Sovjetskog Saveza. ${ }^{30}$ Uprkos započetom procesu isporuke sovjetske vojne tehnike i potpunog kadrovskog restrukturiranja, nijedna od divizija njegovih istočnoevropskih saveznika do kraja 1950. nije bila u stanju visoke borbene gotovosti. Jugoslovenski generalštab je iz sopstvenih obaveštajnih izvora, kao i iz informacija koje su dobijane od strane zapadnih vojnih predstavnika raspolagao saznanjima o jačanju vojnih efektiva svojih suseda, posebno Bugarske i Albanije, putem sovjetskih vojnih isporuka, formiranja novih formacija i povećanja brojnog stanja ljudstva, kao i o njihovom rasporedu, posebno koncentraciji u blizini jugoslovenskih granica. ${ }^{31}$ Često se dešavalo da informacije dobijene iz sopstvenih obaveštajnih izvora, kao i od zapadnih vojnih i diplomatskih predstavnika ne odgovaraju stvarnom stanju, odnosno da je realna vojna moć sovjetskih saveznika u jugoslovenskom okruženju često bila precenjena. ${ }^{32}$

$\mathrm{U}$ isto vreme, i sovjetske vojne snage u jugoslovenskom okruženju su bile skromnog karaktera i kapaciteta. Na tlu Bugarske i Albanije su se nalazili samo vojni instruktori i savetnici dok je na prostoru Rumunije i Mađarske bilo svega nekoliko oklopnih i mehanizovanih divizija. U Rumuniji se nalazila Samostalna mehanizovana armija koja je u datim momentima imala svega tri mehanizovane divizije od kojih je jedino 2. gardijska mehanizovana bila dislocira-

${ }^{30}$ АПРФ, ф. 3, о. 1, д. 362, л. 88-98, Сопроводительная записка начальника Генерального штаба С. М. Штеменко и заместителя начальника Генерального штаба М. В. Захарова И. В. Сталину и информация главного военного советника при Министерстве обороны Румынии генерал-лейтенанта Колганова о работе ЦК РРП в армии, 17 января 1950.

${ }^{31}$ Vojni arhiv, Arhiva JNA, Odeljenje za vezu sa inostranim vojnim predstavnicima (VA, AJNA, OZV), inventarski broj 65, Zapisnik o poseti pomoćnika vojnog atašea Velike Britanije majora Ramsaya ovom Odeljenju na dan 7. aprila 1951. godine u 11,20 časova; VA, AJNA, OZV, inventarski broj 66, Zapisnik o poseti vojnog atašea Velike Britanije, pukovnika Bačelora (u Sofiji) i njegovom razgovoru s admiralom Manolom u ovom Odeljenju na dan 8. aprila 1951. u 16,30 časova; VA, AJNA, OZV, inventarski broj 69, Zapisnik o poseti vojnog atašea SAD pukovnika Condon-a, ovom Odeljenju na dan 25. aprila 1951. u 11,00 časova; VA, AJNA, OZV, inventarski broj 72, Zapisnik o poseti vazduhoplovnog atašea SAD, pukovnika Burnetta ovom Odeljenju na dan 5. maja 1951, u 11,30 časova; VA, AJNA, OZV, inventarski broj 73, Zapisnik o poseti vojnog atašea SAD, pukovnika Condon-a, ovom Odeljenju na dan 7. maja 1951. u 10,30 časova; VA, AJNA, OZV, inventarski broj 74, Zapisnik o poseti vazduhoplovnog atašea SAD, pukovnika Burneta na dan 8. maja 1951, u 11,30 časova; VA, AJNA, OZV, inventarski broj 85, Zapisnik o poseti vojnog atašea SAD, pukovnika Condon-a, ovom Odeljenju na dan 28. septembra 1951. u 9,00 časova; VA, AJNA, OZV, inventarski broj 88, Zapisnik o poseti vazduhoplovnog atašea $\mathrm{SAD}$, pukovnika Burneta na dan 6. oktobra 1951, u 11,30 časova.

32 Анатолий С. Аникеев, „Югославия в годы конфликта с СССР и странами народной демократии“, у: Москва и Восточная Европа. Советско-югославский конфликт и страны советского блока 1948-1953 г2. Очерки истории, редактор А. С. Аникеев (Москва: ИнСлав РАН, 2017), 96-98. 
na u blizini jugoslovenske granice. Na teritoriji Mađarske i sovjetske okupacione zone u Austriji nalazila se Centralna grupa vojske čija se glavnina nalazila na tlu Austrije, orijentisana prevashodno ka zapadu sa svega dve mehanizovane divizije na prostoru Mađarske. ${ }^{33}$

S tim vojnim snagama su mogle biti izvedene vojne operacije ograničenog karaktera, ali njihovi ukupni kapaciteti, ni po borbenom kvalitetu, ni po masovnosti nisu omogućavali preduzimanje vojnih akcija koje bi mogle da dovedu do odlučujućih vojnih uspeha u slučaju organizovanog jugoslovenskog otpora. Na američkoj strani se sredinom 1949. smatralo da Jugoslovenska armija kao „druga po veličini i sposobnosti u Istočnoj Evropi može da pobedi bilo koju kombinaciju armija susednih zemalja satelita“. Procena je temeljena na uverenju da vojne snage jugoslovenskih suseda nisu u stanju da se uz široku sovjetsku logističku podršku osposobe za uspešno vođenje borbe protiv jugoslovenskih snaga u 1949. Odbacivana je i mogućnost direktne sovjetske vojne intervencije. Pretpostavljalo se da bi u slučaju sovjetske vojne pretnje jugoslovensko vrhovno komandovanje imalo na raspolaganju 30-60 dana da svoje glavne snage pregrupiše u unutrašnjost teritorije, prevashodno u planinske oblasti južno od Save i Dunava, i na taj način predupredi njihovo uništenje u prvim danima oružanog sukoba sa Sovjetskim Savezom. Kao bitan faktor odvraćanja moguće sovjetske vojne akcije navođena je i ,odlučnost i sposobnost Titovih snaga da se suprotstave, čak i u gerilskom ratovanju“ 34

Vojne procene odbrambene sposobnosti Jugoslavije i njene oružane sile uticale su na američko ministarstvo spoljnih poslova da već u septembru 1949. stane na stanovište da u slučaju oružanog konflikta između Jugoslavije i Sovjetskog Saveza SAD ,ograniče na isporuke Jugoslaviji oružja i finansijsko-ekonomske pomoći“ pri čemu bi se pomoć i podrška Jugoslaviji zasnivale na autoritetu Ujedinjenih nacija. Ruski istoričar Anatolij Anikejev ostavlja mogućnost da su upravo informacije o stavu američkog državnog vođstva prema pitanju vojne i ekonomske pomoći Jugoslaviji u slučaju da bude vojno napadnuta s istoka, a koje su različitim kanalima stizale u Moskvu delovale kao jedan od faktora odvraćanja u kremaljskim krugovima pristalice vojnog rešenja sukoba s Jugoslavijom. ${ }^{35}$

Zapadne vojne i obaveštajne analize govore da se u američkim vojnim krugovima maja 1950. stajalo na stanovištu da istočnoevropske zemlje neće smeti da rizikuju s otpočinjanjem ofanzivnog rata sve dok ne dobiju ozbiljniju podršku sa sovjetske strane. Amerikanci su procenjivali da za efikasan napad na Jugoslaviju treba angažovati najmanje 25-30 sovjetskih divizija uz ozbiljnu vazduhoplovnu podršku i jake oklopno-mehanizovane snage. U suprotnom, Amerikanci su

${ }^{33}$ Владимир И. Феськов, Сухопутные войска. Вооруженные Силы СССР после Второй Мировой войны от Красной армии к Советской (Томск: ТГУ, 2013), 413-420.

${ }^{34}$ Momčilo Pavlović, prir., Dokumenti CIA o Jugoslaviji 1948-1983 (Beograd: Institut za savremenu istoriju, Univerzitet u Beogradu - Fakultet bezbednosti, Službeni glasnik Republike Srbije, 2009), 59.

35 А. С. Аникеев, „Югославия в годы конфликта с СССР и странами народной демократии“, $100-101$. 
smatrali da će vojna akcija s istoka brzo zapasti u pat poziciju. ${ }^{36}$ Za potrebe razgovora s jugoslovenskom stranom, američki generalštab je izradio model moguće vojne agresije na Jugoslaviju s istoka koji je sublimirao američka sagledavanja mogućeg načina vojnog ugrožavanja Jugoslavije od strane Sovjetskog Saveza i njegovih satelita. U momentima izrade modela moguće vojne agresije na Jugoslaviju, američka strana je procenjivala da postojeći režim u Jugoslaviji može biti svrgnut isključivo vojnim putem, kao i da se u odnosu na raniji period vojni položaj Jugoslavije drastično pogoršao s obzirom na naglo jačanje sovjetskih satelita u jugoslovenskom okruženju. Smatralo se da je tokom 1951. moguć vojni napad na Jugoslaviju od strane armija sovjetskih satelita uz potrebnu sovjetsku pomoć. Uprkos procenjenoj mogućnosti napada na Jugoslaviju, američka strana nije sa sigurnošću mogla da tvrdi da će do njega uskoro doći, odnosno da je u Kremlju doneta takva odluka. ${ }^{37}$ Pretpostavka koju je izradio pukovnik Kac koristeći raspoložive obaveštajne podatke o snazi sovjetskih i satelitskih snaga u jugoslovenskom okruženju predstavljena je jugoslovenskoj strani tokom posete generala Koče Popovića Vašingtonu maja 1951, a potom i u vreme posete generala Kolinsa jugoslovenskom generalštabu septembra iste godine. Izrađena je sa uverenjem da bi napad na Jugoslaviju bio izvršen vojnim snagama sovjetskih saveznika, pri čemu bi Sovjeti ostali formalno neutralni, ali bi preuzeli rukovođenje operacijama i logističku podršku saveznika. Na drugoj strani i SAD bi bile formalno van sukoba, ali bi snabdevale jugoslovenske oružane snage. Tokom vašingtonskih i beogradskih razgovora na jugoslovenskoj strani je isticano uverenje da bi svaki napad na Jugoslaviju doveo do momentalnog otpočinjanja trećeg svetskog rata, uz negiranje mogućnosti bilo koje varijante izolovanog sukoba na Balkanu. ${ }^{38}$

Američki generalštab je u svojim modelima pretpostavljenog napada na Jugoslaviju polazio od toga da će Jugoslaviju napasti susedne zemlje - sovjetski sateliti svim raspoloživim snagama, podržane dobrovoljcima iz kominformovskih zemalja i Sovjetskog Saveza. Smatralo se da bi Jugoslavija mogla da suprotstavi 35 divizija opštem napadu koji bi na nju bio usmeren iz tri pravca: iz Mađarske preko Zagreba ka Rijeci, iz Rumunije ka Beogradu i iz Bugarske preko Skoplja ka Albaniji. Pukovnik Kac je procenio da bi ukupne satelitske snage iznosile 34 divizije što je jugoslovenski generalštab smatrao minimalnom projekcijom snaga. Američka pretpostavka je govorila o angažovanju 10 divizija iz Bugarske prema Jugoslaviji, a 4 prema Turskoj i Grčkoj, iz Rumunije 11, Mađarske 10 i Albanije 4. Jugoslovenska strana je smatrala da Rumunija može angažovati 33, Bugarska 24, a Mađarska 28, odnosno ukupno 85 divizija, a da bi Jugoslovenska armija mogla razviti ukupno 45 divizija. ${ }^{39} \mathrm{Na}$ jugoslovenskoj strani se smatralo da sate-

36 The National Archive (TNA), Foreign Office 371 (FO), 87865. P. 4, Review of the Millitary Situation in Hungary; Central Intelligence Reports File, box 216: O.R.E/1950, Evaluation of Soviet - Yugoslav Relations.

${ }^{37}$ M. Pavlović, $n$. d., 71-83.

38 VA, AJNA, GŠ-1, k. 14, f. 7, r. b. 1/1, Zapisnik Prve konferencije održane 17. maja 1951. u Vašingtonu.

39 Александар Животић, Вашингтонска конферениија 1951. Југословенско приближавағе САД (Београд: Завод за уџбенике, 2014), 77-78. 
litske snage samo u slučaju u kome je ostvarena nadmoć u odnosu na jugoslovenske snage u srazmeri $2: 1$ mogu računati na potencijalan brz uspeh, odnosno brzo ovladavanje strategijskim čvorovima na jugoslovenskom prostoru u roku od 24 dana od početka borbenih dejstava. Za razliku od američkog modela, na jugoslovenskoj strani se verovalo da bi u tom slučaju Bugari usmerili jače snage ka Skoplju nego ka Nišu i Zaječaru, da bi rumunske snage dejstvovale i preko Dunava ka dolini Velike Morave, kao i da će u tom slučaju mađarske snage dejstvovati i jednim pomoćnim pravcem ka Osijeku. U pogledu mogućih ofanzivnih akcija Albanije, pukovnik Kac je smatrao da bi njene snage dejstvovale s tri ili četiri divizije ka Makedoniji, a jednom ka Kosovu i Metohiji dok su jugoslovenski generali bili uvereni da bi u toj varijanti težište ofanzive bilo ka Kosovu i Metohiji, a nisu isključivali ni mogućnost albanske neutralnosti savetovane od strane Sovjeta zbog njenog izolovanog položaja u odnosu na ostale istočnoevropske saveznike. ${ }^{40}$ Tokom kasnijih razgovora jugoslovenskih i američkih vojnih predstavnika, posebno na prvoj i drugoj tripartitnoj konferenciji, dolazilo je do razmimoilaženja u pogledu procena mogućnosti napada na Jugoslaviju s istoka, kao i jačine i rasporeda sovjetskih i ,satelitskih“ vojnih snaga u jugoslovenskom okruženju pri čemu je jugoslovenski generalštab insistirao na globalnom karakteru mogućeg sukoba, dok je sovjetsko vojno prisustvo u susedstvu i stvarnu snagu vojnih efektiva njegovih saveznika procenjivao jačim i masovnijim u odnosu na realno stanje. ${ }^{41} \mathrm{Na}$ sličnim postavkama se insistiralo i u razgovorima vođenim s predstavnicima grčkog i turskog generalštaba. ${ }^{42}$

Situacija vezana za proklamovanu sovjetsku politiku jačanja vojnih potencijala jugoslovenskih suseda drastično se izmenila neposredno po okončanju tajnog savetovanja u Moskvi januara 1951. Pored sovjetskog državnog vrha Staljina, Molotova, Berije, ministra odbrane maršala Aleksandra Vasiljevskog i načelnika generalštaba generala armije Sergeja Štemenka, u radu savetovanja su učestvovali i glavni sovjetski vojni savetnici u zemljama Istočne Evrope, kao i lideri komunističkih partija istočnoevropskih zemalja i njihovi ministri odbrane. Iako još uvek nije dostupan stenografski materijal s tog susreta, iz pratećih dokumenata i sećanja pojedinih učesnika razgovora jasno se vidi da je Staljin najavio ubrzano jačanje oružanih snaga svih saveznika, uključujući i jugoslovenskih suseda. S obzirom na utvrđenu nesposobnost istočnoevropskih armija za vođenje savremenog rata, Staljin je stajao na stanovištu da u roku do 2-3 godine treba iz korena izmeniti postojeću situaciju i stvoriti jake vojne snage na istoku Evrope čija će ukupna brojnost dostići oko tri miliona boraca od kojih bio oko 1,2 miliona tokom mira trebalo držati u stanju pune borbene gotovosti kako bi bili sposobni da reaguju u najkraćem mogućem roku i pristupe efikasnom izvođenju borbenih dejstava. Isto tako, po sovjetskim planovima, na tlu Istočne

\footnotetext{
${ }^{40}$ VA, AJNA, GŠ-1, k. 14, f. 6, r. b. 1/1, Konferencija u Generalštabu JNA sa generalom Kolinsom.

${ }^{41}$ Ivan Laković, Zapadna vojna pomoć Jugoslaviji 1951-1958 (Podgorica: Istorijski institut Crne Gore, 2006), 69-147.

42 Milan Terzić, gl. ured., Balkanski pakt 1953-1954. Zbornik dokumenata (Beograd: Vojnoistorijski institut, 2005), 162-181, 182-243, 325-349, 354-521, 525-552.
} 
Evrope je trebalo pripremiti 1,85-2 miliona rezervista koji bi u slučaju rata mogli biti brzo mobilisani i, kao već dobro obučeni, spremni za uključivanje u borbene aktivnosti. Očigledno, radilo se o sovjetskoj reakciji na vojno jačanje zapadnih zemalja i njihovo savezničko organizovanje čemu je trebalo postaviti kontrateg na istoku Evrope. Sovjeti nisu krili zadovoljstvo zbog američkog angažmana u Koreji jer su smatrali da će takva vrsta američke aktivnosti usmeriti njihovu pažnju s Evrope ka Dalekom istoku, čime će Sovjeti i njihovi saveznici dobiti neophodno vreme od dve do tri godine za jačanje svojih efektiva $u$ Evropi. O nesposobnosti istočnoevropskih vojnih snaga za jaču akciju jasno govore i rezolutni stavovi poljskog ministra odbrane sovjetskog maršala Rokosovskog, koji se usprotivio ambicioznim sovjetskim planovima ističući da puna borbena gotovost istočnoevropskih armija neće biti dostignuta pre kraja 1956. Slične stavove je delio i lider bugarskih komunista Vlko Červenkov, ali su Sovjeti ostali nepomirljivi insistirajući na kraćim rokovima. Istovremeno su preduzete mere za jačanje sovjetskih vojnih efektiva koji su sa 12 miliona na kraju rata 1945. do 1948. svedeni na 2,9 miliona, da bi do marta 1956. dostigli 5,6 miliona ljudi. U sklopu jačanja sovjetskih vojnih kapaciteta u zapadnim delovima zemlje ojačane su i jedinice na prostoru Ukrajine i Moldavije, koje su mogle biti upotrebljene u slučaju donošenja odluke o preduzimanju vojne intervencije u Jugoslaviji. Istovremeno su ojačani i sovjetski kapaciteti u samoj rezervi prvog reda, pa je sovjetska armija nakon 30 dana od početka mobilizacije mogla da računa na oružane snage jačine oko 10 miliona ljudi. Svakako, rast oružanih snaga zemlje koja je sveže izašla iz rata s ogromnim ljudskim i materijalnim gubicima bio je bez presedana, ali je prvenstveno predstavljao reakciju na političke i vojne izazove koji su dolazili sa zapada Evrope. ${ }^{43}$ Mere koje su u tom periodu preduzete na planu jačanja vojnih snaga Sovjetskog Saveza i njegovih satelita tek nakon 1953. mogle su da daju očekivane rezultate prevashodno na planu podizanja opšteg nivoa operativnih sposobnosti i opremljenosti savremenim sredstvima naoružanja i vojne opreme koje ni po jednom parametru nisu mogle dostići u periodu između 1948. i $1950 .^{44}$

Koraci koji su inicirani sa sovjetske strane počeli su da daju rezultate veoma brzo. Početkom 1952, ukupne snage sovjetskih saveznika u jugoslovenskom okruženju iznosile su 38 divizija s gotovo 600.000 ljudi što je bilo osetno više u odnosu na jugoslovensku vojsku koja nije mogla da povisi brojku od 400.000 ljudi, a čije je držanje praktično iscrpljivalo jugoslovenske mobilizacijske, demografske i materijalne resurse. Praktično, do Staljinove smrti savezničke snage na jugoslovenskim granicama su dostigle planiranu brojku od 1,2 miliona ljudi. ${ }^{45}$ Uprkos ubrzanom jačanju vojnih potencijala jugoslovenskih suseda na američkoj

\footnotetext{
${ }^{43}$ М. Крамер, „Советско-югославский конфликт...“, 264-266.

${ }^{44} \mathrm{O}$ sovjetskoj politici jačanja vojnih efektiva zemalja saveznica opširnije: Mark Kramer, ,Stalin, Soviet Policy, and the Consolidation of a Communist Bloc in Eastern Europe, 1944-53", u: Stalinism Revisited. The Establishment of Communist Regimes in East-Central Europe, editor Vladimir Tismeaunu (Budapest: CEU, 2009), 51-101.

45 CIA NIE, Probably Developments in Yugoslavia and Likelihood of Attack upon Yugoslavia through 1952.
} 
strani se verovalo da je mogućnost vojne agresije na Jugoslaviju u toku 1952. minimalna. Smatralo se da povećanje vojnih efektiva ne predstavlja pouzdan indikator mogućeg napada na Jugoslaviju jer bi, prema zapadnim procenama, Sovjeti svakako ojačali vojne kapacitete svojih saveznika nezavisno od planova moguće vojne intervencije u Jugoslaviji. Procenjivalo se da će bugarske, rumunske i mađarske oružane snage dostići planiran nivo razvoja tek u 1953, a albanske 1954. Isto tako, nije bilo nikakvih indikacija ni da su dugoročni ciljevi ekonomskog razvoja satelitskih zemalja usmereni na jačanje vojnih kapaciteta. Smatralo se da na sovjetskoj strani postoji čvrsto uverenje da Jugoslavija ne predstavlja vojnu pretnju po sovjetske satelite, ali da se njen slučaj ne može posmatrati kao izolovan problem već kao jedan od više faktora koji mogu ugroziti sovjetske interese. Zato se stajalo na stanovištu da Sovjeti ni u kom slučaju neće pokrenuti vojnu akciju bez pažljivije procene mogućih posledica koje bi takav napad imao na opštu sovjetsku stratešku poziciju. Uz to, sve bliža saradnja između Jugoslavije i zapadnog sveta smatrana je ključnim faktorom odvraćanja jer bi sovjetski ili ,satelitski napad“" na Jugoslaviju otvorio mogućnost rata između SSSR-a i SAD koji bi mogao da se razvije u sukob planetarnih razmera. ${ }^{46}$

Na kvalitativnoj strani, naoružanje i vojna oprema bugarske i rumunske strane, pa samim tim i vatrena moć njihovih jedinica drastično su povećane, dok se u mađarskom i albanskom slučaju to desilo u nešto manjem obimu. Preduzete sovjetske mere su dovele do drastičnije izmene postojećeg balansa u odnosu na jugoslovensku stranu koja do početka 1951. nije mogla da računa na nove modele naoružanja i vojne opreme, potrebnu municiju i rezervne delove. Tek će jugoslovensko pristupanje programu zapadne vojne i ekonomske pomoći izmeniti situaciju i uvesti Jugoslaviju u početku stidljivo, a potom i najdirektnije pod zaštitu zapadnog vojnog i političkog saveza što je suštinski iz korena izmenilo njenu geostrategijsku poziciju. Na Zapadu je i nakon uspostavljanja čvrstih vojnopolitičkih aranžmana s Jugoslavijom postojao strah da njene oružane snage i dalje raspolažu malom količinom zastarele vojne tehnike bez potrebnih rezervnih delova i adekvatne količine svih vrsta municije, da je izražen nedostatak teškog naoružanja, posebno protivavionske i protivoklopne artiljerije, ali i da jugoslovenski generalštab nema potrebnog iskustva u vođenju savremenih borbenih operacija koje podrazumevaju taktičku i tehničku primenu sadejstva različitih rodova vojske. Zapad, prevashodno SAD, zabrinjavala je činjenica da jugoslovenska vojska uprkos zapadnoj vojnoj pomoći oličenoj u isporuci uglavnom starijih modela naoružanja i vojne opreme osetno zaostaje za armijama sovjetskih saveznica u svom susedstvu koje se ubrzano modernizuju i brojčano rastu u sklopu sovjetskih priprema za slučaj rata na evropskom tlu. ${ }^{47}$

U prvom redu, sovjetski ratni planovi su bili usmereni ka odvraćanju mogućeg napada sa Zapada ili njegovom odbijanju ukoliko bi do agresije došlo, ali je sovjetski generalštab stajao na stanovištu da varijanta rata s NATO-om ne

\footnotetext{
${ }^{46}$ M. Pavlović, $n$. d., 83-91.

${ }^{47}$ VA, AJNA, GŠ-1, k. 14, f. 7, r. b. 1/1, Zapisnik Prve konferencije održane 17. maja 1951. u Vašingtonu, 19.
} 
može biti razmatrana odvojeno od moguće vojne operacije protiv Jugoslavije. Preduzete mere na planu jačanja savezničkih snaga u defanzivne svrhe su se u slučaju potrebe lako mogle prilagoditi potrebama vojne intervencije u Jugoslaviji. Tome u prilog ide i činjenica da su od januara 1951. započele isporuke jačih grupacija bombarderske avijacije savezničkim armijama uz obrazloženje da se radi o sredstvima koja imaju zadatak da snažno podrže ofanzivne operacije ukoliko se za njima bude ukazala potreba. U narednim godinama, kad su nastojanja na planu jačanja savezničkih snaga počela da daju izvesne rezultate, u letnjim mesecima 1951. i 1952. organizovani su masovni vojni manevri jedinica albanske, bugarske, rumunske i mađarske vojske. Osnovnu pretpostavku za izvođenje manevara dali su sovjetski vojni savetnici. Pretpostavke su podrazumevale razvoj jedinica u borbeni poredak, izvođenje masovnih ofanzivnih operacija u cilju okruženja, a potom i likvidacije protivničkih snaga na jugoslovenskoj teritoriji. Na tim manevrima mađarska strana je bila zadužena za ovladavanje Beogradskom oblašću. Takav zadatak je bio pretpostavljen kao cilj kontranapada prema snagama koje su prethodno izvršile napad na Mađarsku, ali su mogle biti iskorišćene i za napad na Jugoslaviju. Rumunske i bugarske vojne snage su izvodile svoje manevre na pravcima koji su podrazumevali moguće operacije ka jugoslovenskoj teritoriji. S tim u vezi, rumunska vlada je u leto 1951. započela s nasilnim preseljenjem oko 40.000 Srba iz Banata u Baragansku pustaru sumnjajući u njihovo držanje u slučaju rata s Jugoslavijom, bilo u slučaju rumunskog učešća u intervenciji protiv Jugoslavije, bilo u slučaju napada s jugoslovenske teritorije, jugoslovenskih ili NATO snaga. ${ }^{48}$

Nakon preseljenja stanovništva, na tom prostoru su organizovani masovni vojni manevri tokom kojih su proigravane varijante reakcija na masovan jugoslovenski proboj preko rumunskih granica. Kroz različite uslovno zamišljene varijante poput „organizovanja obimnih kopnenih i vazdušnih ofanzivnih operacija u složenim uslovima“, zatim ,koncentracije nadmoćnih snaga u cilju proboja odbrane protivnika“, ili ,angažovanje snaga u skladu s optimalnim planom napada“, najviši štabovi armija jugoslovenskih suseda uvežbavani su za izvođenje obimnih vojnih operacija na jugoslovenskoj teritoriji koja je nakon ozvaničenja jugoslovenskog pristupanja programu zapadne vojne i ekonomske pomoći smatrana mogućim prostorom budućih borbenih dejstava. Odnosno, teritorijom zemlje koja suštinski pripada zapadnom vojnom savezu i koja bi mogla biti iskorišćena kao prostor s koga će biti izvršen napad na sovjetske saveznice.

Naglo jačanje sovjetske armije i oružanih snaga istočnoevropskih zemalja koje su pripadale sovjetskom bloku postalo je realna vojna opasnost za Jugoslaviju tek sredinom 1952. Američke analize koje datiraju s kraja 1951, a koje se hronološki poklapaju s ratifikacijom sporazuma o američkoj vojnoj pomoći Jugoslaviji čime je ona suštinski postala partner i saveznik SAD, govore da su snage sovjetskih satelita u jugoslovenskom okruženju dostigle stepen razvoja

48 М. Крамер, „Советско-югославский конфликт...“, 264-266. О јас̌anju rumunske armije opširnije: Denis Deletant, Mihai Ionescu, Romania and the Warsaw Pact 1955-1989 (Washington: Cold War International History Project - Working Papers 43, 2004). 
koji im omogućava samostalnu uspešnu akciju protiv Jugoslavije bez direktne vojne pomoći SSSR-a. Po njima, reformom oružanih snaga sovjetskih saveznika stvorena je baza za moguće nastupanje ka Jugoslaviji zbog čega mogućnost napada sa istoka na Jugoslaviju treba smatrati sve ozbiljnijom. Zaključivali su da su Sovjeti zajedno sa svojim saveznicima spremni da okupiraju zemlju, unište jugoslovensku armiju i da postepeno u potpunosti uguše partizanski otpor na njenoj teritoriji. Po njima, jačanje armija susednih istočnoevropskih zemalja, odnosno brojno uvećanje vojski, gomilanje rezervi, preoružanje savremenim modelima naoružanja, stvaranje zaliha goriva, kao i ubrzan razvoj vojne industrije, izmenili su raniji balans snaga između njih i Jugoslavije što im daje mogućnost da se bez većih strahova odluče na krupniju akciju protiv nje. Smatralo se da ujedinjene sovjetske i savezničke snage mogu uspešno da izvrše upad na jugoslovensku teritoriju, savladaju otpor regularnih vojnih snaga i da u samoj završnici učine besmislenim partizanske operacije. To je u osnovi potvrđivalo $i$ jugoslovensku poziciju iznetu tokom pregovora koje je načelnik generalštaba general Koča Popović vodio u Vašingtonu maja i juna 1951. On je tom prilikom analizirajući odnos snaga između sovjetskih satelita i Jugoslavije izneo uverenje da su satelitske zemlje po svim parametrima - jačina oružanih snaga, industrijski potencijal, brojnost i sovjetska pomoć, jače od Jugoslavije i njene armije. Smatrao je da postoje dve mogućnosti napada na Jugoslaviju - izolovan napad satelitskih snaga i njihov zajednički napad sa sovjetskim snagama pri čemu bi se u oba slučaja napad odvijao uz snažnu sovjetsku podršku, po sovjetskim direktivama i uz strogu sovjetsku kontrolu. Sem toga, odbacio je mogućnost izolovanog sukoba istakavši da bi napad na Jugoslaviju značio početak trećeg svetskog rata. Američka strana se u načelu saglasila s Popovićevim procenama, naglašavajući da raspolaže informacijama da Sovjeti jačaju satelitske snage i da je jedan od razloga i jačanje pritiska na Jugoslaviju, pri čemu je izrazila uverenje da je jugoslovenska strana odlučna da pruži otpor svakom vidu agresije. ${ }^{49}$

Načelnik američkog generalštaba general Kolins je stajao na stanovištu da je izolovan napad Sovjetskog Saveza na Jugoslaviju malo verovatan, jer bi po njegovoj proceni takav korak izazvao i mobilizaciju u drugim zemljama koje bi se osetile ugroženim što bi dovelo do razbuktavanja sukoba. On je bio skloniji verovanju da će SSSR u slučaju rata usmeriti glavninu svojih snaga Podunavljem ka Beču, a da tom prilikom neće ostaviti svoje levo krilo nezaštićenim, pa će iz tog razloga uslediti i napad na Jugoslaviju. ${ }^{50}$

Iako su vojni efektivi Sovjeta i njihovih saveznika u jugoslovenskom okruženju rasli, ne može se zaključiti na osnovu dostupnih izvora da je postojala namera da se izvrši vojna intervencija. Unutar sovjetskog generaliteta vladalo je uverenje da na Balkanskom poluostrvu može doći do ozbiljnih incidenata koji bi bili izazvani s anglo-američke strane. U prilog takvoj tezi navođeno je gomilanje

\footnotetext{
49 VA, AJNA, GŠ-1, k. 14, f. 7, r. b. 1/1, Zapisnik Prve konferencije održane 17. maja 1951. u Vašingtonu, str. 10.

${ }^{50}$ VA, AJNA, GŠ-1, k. 14, f. 6, r. b. 1/1, Konferencija u Generalštabu JNA sa generalom Kolinsom, 20; I. Laković, n. d., 56.
} 
britanskih pomorskih snaga u Sredozemlju, što je bilo u direktnoj vezi s komplikovanjem situacije u oblasti Sueckog kanala. Verovalo se da bi „Britanci poznajući bugarsku i rumunsku vojnu slabost mogli uz pomoć Jugoslavije da isprovociraju vojne incidente na Balkanu koji bi mogli dalje prerasti u vojnu agresiju“, što je jasno govorilo o sovjetskom strahu da bi u slučaju usložnjavanja vojnopolitičke situacije u regionu Sredozemlja, Balkan mogao postati krizno žarište, a jugoslovenska teritorija prostor sa koga bi zapadni vojni savez vojno ugrozio sovjetske saveznike, pa samim tim i sovjetske vojne i političke pozicije u tom delu Evrope. ${ }^{51}$ Američke analize iz 1952. govore da je na američkoj strani mogućnost vojnog napada na Jugoslaviju smatrana do kraja te godine malo verovatnom. ${ }^{52} \mathrm{Na} Z$ Zapadu su se i druge mere koje su preduzimali jugoslovenski susedi, a ticale su se evakuacije industrijskih postrojenja i stanovništva iz pograničnih rejona s Jugoslavijom smatrale psihološko-propagandnom pripremom opravdanja oružane intervencije u Jugoslaviji, ali ne i sigurnim znakom priprema skorašnje vojne intervencije. Pri tom je jasno prenebregavana mogućnost da jugoslovenski susedi pribegavaju takvim merama strahujući da bi u potencijalnom sukobu između Istoka i Zapada jugoslovenska teritorija mogla biti iskorišćena za napad na članice sovjetskog vojnog bloka. Takođe su pretpostavljali da Sovjetski Savez čak i ako donese odluku o vojnom angažmanu u Jugoslaviji neće započeti s njenom realizacijom pre kraja 1953, odnosno ne pre trenutka u kome će armije njegovih istočnoevropskih saveznika dostići projektovanu borbenu gotovost, dok se za albansku armiju procenjivalo da će se ona nalaziti na planiranom nivou tek sredinom $1954 .^{53}$

Staljin je umro u martu 1953, pre nego što je završen plan reorganizacije i modernizacije sovjetske armije i oružanih snaga njegovih saveznika. Suštinski, do poslednjeg svog dana on se bavio pitanjima i problemima vezanim za jačanje vojnih efektiva SSSR i istočnoevropskih saveznika postavljajući osnovu za moguću vojnu intervenciju u Jugoslaviji, bez obzira na to da li se o njoj razmišljalo samo kao o načelnoj mogućnosti ili realnoj varijanti s određenim terminom početka i jasno opredeljenim zadacima i ciljevima. Sasvim je jasno da glavni cilj započetih vojnih reformi u SSSR-u i zemljama koje su gravitirale ka njemu nije predstavljao dostizanje sposobnosti za vojnu intervenciju u Jugoslaviji. Sovjetski Savez je sa svojim saveznicima, uz određena naprezanja, pregrupisanja snaga i druge napore to svakako mogao učiniti s obzirom na ogromne vojne kapacitete kojima je raspolagao. Glavni cilj ubrzanog narastanja vojnih snaga bio je usko povezan s dešavanjima na prostoru Evrope i Dalekog istoka u prvom redu. Formiranje NATO pakta i širenje ratnog sukoba na Korejskom poluostrvu silno su uticali na stvaranje adekvatnog vojnog odgovora na Istoku. U tom smislu, Jugoslavija je za Sovjetski Savez dobila sasvim drugačiji značaj. Od trenutka kad je uspo-

\footnotetext{
${ }^{51}$ АПРФ, ф. 3, о. 66, д. 804, л. 142-147, Сопроводительно письмо С. М. Штеменко И. В. Сталину с приложением донесения старшего военного советника при командующем химическами войсками Чехословацкой армии полковника Наумкина, 16 января 1952.

52 CIA NIE, Probably Developments in Yugoslavia and Likelihood of Attack upon Yugoslavia through 1952.

${ }^{53}$ Isto.
} 
stavila blisku saradnju sa zapadnim svetom i počela da dobija zapadnu vojnu i ekonomsku pomoć, ona je u sovjetskim očima postala deo zapadnog sveta i suštinska, mada ne i formalna članica zapadnog vojnog saveza, pa je njena teritorija razmatrana kao deo potencijalnog poprišta sukoba između bloka zemalja predvođenog Sovjetskim Savezom i Severnoatlantske vojne alijanse. Sama činjenica da se Jugoslavija graničila s četiri sovjetske saveznice i da je njeno približavanje zapadnom vojnom savezu značilo pomeranje potencijalne linije sukoba za 500 kilometara u proseku ka istoku, za Sovjete je imala poseban značaj, pa je to uslovilo i sovjetski pogled na nju i njenu ulogu u projekcijama potencijalnog sukoba. Isto tako, iz analize dostupnih izvora jasno proizilazi da na sovjetskoj strani nije postojala odluka o započinjanju vojne intervencije protiv Jugoslavije. Bez obzira na oštro narastanje vojnih snaga u jugoslovenskom okruženju i sovjetske jasne namere da u Jugoslaviji poseje strah od mogućeg vojnog napada, dokaza o rešenosti Kremlja da se vojnim sredstvima obračuna s vođstvom jugoslovenskih komunista nema. Posebno pitanje je u kojoj i kakvoj meri su zapadni saveznici želeći da prodube postojeće jugoslovensko-sovjetske protivrečnosti sistematski jačali jugoslovenski strah od mogućeg vojnog napada s istoka.

Vojna intervencija Sovjetskog Saveza i njegovih istočnoevropskih saveznika - jugoslovenskih suseda nije bila moguća bez ozbiljnijeg tehničkog i logističkog angažovanja Sovjetskog Saveza pre kraja 1951. Tek od početka 1952, ona je bila izvodljiva savezničkim snagama uz ograničen sovjetski angažman, ali je jugoslovensko pristajanje uz zapadni svet za sobom u tom slučaju neminovno povlačilo i direktno mešanje zapadnih zemalja, prvenstveno $\mathrm{SAD}$, Velike Britanije i Francuske u već započet oružani konflikt. Istovremeno, promene do kojih je došlo u Sovjetskom Savezu nakon Staljinove smrti i prvi znaci normalizacije odnosa s Jugoslavijom činili su i samu ideju o mogućoj vojnoj intervenciji u Jugoslaviji besmislenom.

\section{REFERENCE}

- Anikeev, Anatolij S. Kak Tito ot Stalina ushel: Yugoslaviya, SSSR i SShA $i$ nachal"ny period xolodnoj vojny 1945-1957. Moskva: InSlav RAN, 2002.

- Anikeev, Anatolij S. „Yugoslaviya v gody konflikta s SSSR i stranami narodnoj demokratii“. U: Moskva i Vostochnaya Evropa. Sovetsko-yugoslavskij konflikt i strany sovetskogo bloka 1948-1953 gg. Ocherki istorii. Redaktor A. S. Anikeev, 15-104. Moskva: InSlav RAN, 2017.

- Bekić, Darko. Jugoslavija u Hladnom ratu. Odnosi s velikim silama 19491955. Zagreb: Globus, 1988.

- Berić, Gojko. Zbogom XX. stoljeće. Sjećanja Ive Vejvode. Zagreb: Profil, 2013.

- Bjelajac, Mile. Diplomatija i vojska. Srbija i Jugoslavija 1901-1999. Beograd: Odbrana, 2010.

- Bogetić, Dragan. Jugoslavija i Zapad, 1952-1955. Jugoslovensko približavanje NATO-u. Beograd: Službeni list SRJ, 2000. 
- Bystrova, Irina. ,Voennaya politika stalinskogo rukovodstva: osnovnye vexi i mexanizmy osushhestvleniya“. U: Stalin i xolodnaya vojna. Redaktor A. O. Chubar'yan, 228-253. Moskva: IVI RAN, 1998.

- Bystrova, Irina. Sovetskij voenno-promyshlennyj kompleks: problemy stanovleniya i razvitiya 1930-1980-e gody. Moskva: IVI RAN, 2006.

- Dedijer, Vladimir. Izgubljena bitka Josifa Visarionoviča Staljina. Sarajevo: Svjetlost, 1968.

- Dedijer, Vladimir. Novi prilozi za biografiju Josipa Broza Tita III. Zagreb: Mladost, 1984.

- Deletant, Denis, Mihai Ionescu. Romania and the Warsaw Pact 1955-1989. Washington: Cold War International History Project Bulletin - Working Papers 43, 2004.

- Dimitrijević, Bojan. JNA od Staljina do NATO pakta. Beograd: Službeni list SCG, 2006.

- Đilas, Milovan. Vlast i pobuna. Beograd: Književne novine, 1991.

- Đilas, Milovan. Razgovori sa Staljinom. Beograd: Književne novine, 1991.

- Fes'kov, Vladimir I. Suxoputnye vojska. Vooruzhennye Sily SSSR posle Vtoroj Mirovoj vojny ot Krasnoj armii k Sovetskoj. Tomsk: TGU, 2013.

- Gibianskij, Leonid Ya. „K istorii sovetsko-yugoslavskogo konflikta 19481953: Sekretnaya sovetsko-yugoslavo-bolgarskaya vstrecha v Moskve 10. fevralya 1948. goda“. I. Slavyanovedenie, br. 3, (1991), 12-23; II. Slavyanovedenie, br. 4, (1991), 4-36; III. Slavyanovedenie, br. 1, (1992), 42-56; IV. Slavyanovedenie, br. 3, (1992), 35-51.

- Girenko, Yurij. Stalin-Tito. Moskva: IPL, 1991.

- Xrushhev, Nikita S. Vremya, lyudi, vlast', kn. 3. Moskva: Moskovskie novosti, 1994.

- Jakšić, Pavle. Nad uspomenama II. Beograd: Rad, 1990.

- Kiraly, Bela K. "The Aborted Soviet Military Plans Against Tito's Yugoslavia". In: At the Brink of War and Peace. The Tito - Stalin Split in a Historic Perspective. Editor Wayne Vucinich, 273-278. New York: East European Monographs, 1982.

- Kramer, Mark. "Stalin, Soviet Policy, and the Consolidation of a Communist Bloc in Eastern Europe, 1944-53". In: Stalinism Revisited. The Establishment of Communist Regimes in East-Central Europe. Editor Vladimir Tismeaunu, 51-101. Budapest: CEU, 2009.

- Kramer, Mark. „Sovetsko-yugoslavskij konflikt, sovetskaya voennaya politika o popytki Stalina vernut' sebe kontrol' nad Yugoslaviej: pereocenka“. U: Istoriya stalinizma: itogi problemy izucheniya. Urednik Elena Kandrashina, 256274. Moskva: ROSSPE'N, 2011.

- Laković, Ivan. Zapadna vojna pomoć Jugoslaviji 1951-1958. Podgorica: Istorijski institut Crne Gore, 2006.

- Laković, Ivan, Dmitar Tasić. The Tito-Stalin Split and Yugoslavia's Military Opening toward the West, 1950-1954. New York: Lexington Books, 2017. 
- Lis, Lorejn M. Održavanje Tita na površini. Sjedinjene Države, Jugoslavija i Hladni rat. Beograd: AGM, 2003.

- Ognyanov, Lyubomir. Politicheskata sistema v B"lgariya 1949-1956. Sofiya: Standart, 2008.

- Pavlović, Momčilo, prir. Dokumenti CIA o Jugoslaviji 1948-1983. Beograd: Institut za savremenu istoriju, Univerzitet u Beogradu - Fakultet bezbednosti, Službeni glasnik Republike Srbije, 2009.

- Petranović, Branko. Jugoslavija na razmeđu 1945-1950. Podgorica: CANU, 1998.

- Petranović, Branko. Velika šizma. Četrdesetosma. Podgorica: CID, 1999.

- Ritter, Laszlo. "War in Tito's Yugoslavia? The Hungarian Army in early Cold War Soviet strategies”. U: Balkanski pakt 1953-1954. Zbornik radova. Urednik Milan Terzić, 251-281. Beograd: Vojnoistorijski institut, 2008.

- Simić, Pero. Titov dnevnik. Beograd: Večernje novosti, 2009.

- Štrbac, Čedomir. Svedočanstva o 1948. Beograd: Zavod za udžbenike i nastavna sredstva, 1989.

- Tasić, Dmitar, „Neostvarena pretnja (mogućnost sovjetsko-satelitske agresije na FNRJ 1948-1953)“. Vojnoistorijski glasnik, br. 1, (2009), 81-98.

- Terzić, Milan, gl. ured. Balkanski pakt 1953-1954. Zbornik dokumenata. Beograd: Vojnoistorijski institut, 2005.

- Terzić, Milan, Mihajlo Basara, Dmitar Tasić. Jugoslovenska (narodna) armija i Informbiro. Zbornik dokumenata. Beograd: Službeni glasnik, 2015.

- Ulunyan, Artem A. SSSR, strany narodnoj demokratii i revolyucionnoe dvizhenie v Grecii 1944-1950. Moskva: IVI AN SSSR, 1988.

- Ulunyan, Artem A. Balkany. Goryachij mir xolodnoj vojni 1945-1960. Moskva: IVI RAN, 2001.

- Volokitina, Tat'yana, Galina Murashko, Al'bina Noskova, Tat'yana Pokivajlova. Moskva i Vostochnaya Evropa. Stanovlenie politicheskix rezhimov sovetskogo tipa (1948-1953): Ocherki istorii. Moskva: ROSSPE'N, 2008.

- Vykoukal, Jiri, Bohuslav Litera, Miroslav Tejchman. Východ, vznik, vývoj a pozpad sovětskeho bloku 1944-1989. Praha: Libri, 2000 .

- Životić, Aleksandar. Jugoslavija, Albanija i velike sile, 1945-1961. Beograd: Arhipelag, 2011.

- Životić, Aleksandar. Vašingtonska konferencija 1951. Jugoslovensko približavanje SAD. Beograd: Zavod za udžbenike, 2014.

- Životić, Aleksandar. Jugoslovensko-sovjetske vojne suprotnosti (1947-1957). Iskušenja savezništva. Beograd: Arhipelag, 2015. 
ALEKSANDAR ŽIVOTIĆ, PhD, Associate Professor

Faculty of Philosophy, University of Belgrade

Belgrade, Republic of Serbia

aleksandar.zivotic@f.bg.ac.rs

\title{
FEAR OR REALITY? \\ THE POSSIBILITY OF SOVIET MILITARY INTERVENTION IN YUGOSLAVIA 1948-1953
}

\begin{abstract}
Summary
The beginning of the conflict between Yugoslavia and the countries gathered around the Soviet Union had different political, ideological, economic, and military dimensions. In the moments of the flare-up of the conflict in the autumn of 1949, the Yugoslav side became convinced that the state was facing the threat of military intervention by the Soviet Union and its "satellites". Therefore, the question arises whether it was a real threat of armed aggression, fear that arose as a result of confronting erstwhile allies, or the political means of Western countries that were supposed to deepen the existing conflict and bring Yugoslavia closer to the Western world? The escalation of the conflict, the intensity of the anti-Yugoslav campaign in the media of the Eastern European countries, frequent border incidents and the strengthening of Soviet and "satellite" military forces in the area, made the Yugoslav military authorities suspect preparations for military intervention. At the same time, appraising that Yugoslavia could find itself under the auspices of the Western world only in the event of a sense of danger from the East, the United States and Great Britain sought to strengthen the fear of Soviet military engagement in the Balkans through various political, military, and psychological propaganda measures and thus accelerated the process of a comprehensive Yugoslav "road to the West". An analysis of Soviet and Warsaw Pact sources clearly indicates that there was no plan for military intervention in Yugoslavia and that the military buildup in the "satellite" countries was in response to the creation of the North Atlantic Alliance.
\end{abstract}

KEYWORDS: Yugoslavia, Soviet Union, Great Britain, United States, Cominform, Military Intervention 